\title{
ENGLISH FOR SPECIFIC PURPOSES AS A LINGUISTIC RESPONSE TO GLOBALIZATION
}

Nadežda Stojković, University of Niš, nadezda.stojkovic@elfak.ni.ac.rs

10.31902/fll.25.2018.1

UDK 811.111'243(100)

\begin{abstract}
English for Specific Purposes is one of the most recent strains in English language teaching that appeared in the second half of the previous century following the wider societal trends subsumed under the term globalization. ESP is a narrowly, domain focused linguistic instruction in professional communication, the main goal being functional interaction. Language therefore becomes an instrument for achieving higher performativity. In such an educational setting, its core characteristic of being an ontology is disregarded. Thus, arguments will be presented here examining hidden cultural issues in the syllabus of English for Specific Purposes course. It will argue against the proposition that such syllabus is culturally void being supposedly focused on expert language only and for critical approaches to be integrated in this approach to English language instruction..
\end{abstract}

Keywords: English for Specific Purposes, globalization, performativity, language, content.

\section{Basic features of English for Specific Purposes}

The concept of English for Specific Purposes is a relatively new phenomenon, starting approximately in 1960's and in its appearance and growth largely corresponding with the advent of globalization. It is justifiable to say that ESP is a yet unacknowledged response of teaching English as a foreign language to the demands of the 'new world order' that globalization has initiated. The English curricula has been responding to the new demands thus put forward, primarily in the form of segmenting the so-called English for General Purposes into ever more numerous branches of English for Specific, English for Occupational, Vocational, Academic Purposes, and the like, the categorizations being many. English for Specific Purposes is a form of English language teaching that focuses on teaching English language with a particular pre-set aim, goal. That aim is usually to empower a student to use language in a target professional situation. Language content thus presented consists of that profession specific vocabulary, typical syntax structures, usual morphological processes that characterise word formation in that area of expertise, appropriate 
style. Instruction is mainly done in the form of simulations of the linguistic communicative professional situations. The question raised here is the effect of the absence of all the riches, potential, cultural and historical knowledge that is contained within a language and which is now intentionally left out in ESP syllabus, which can be viewed as following the trends of a primarily utilitarian global society that values immediately 'usable' language over the knowledge of culture.

However, what needs to be noted in the occurrence and the unstoppable spread of ESP is that in it only a particular set of language abilities are targeted, the rationale for this being the answer to the very first premise of the justification of its existence, namely its relation to a specifically predetermined purpose which requires a specialized practice of specific language skills. Due to this, English language teaching has become straightforwardly instructive; it is construed as a method to adopt in order to achieve specific ends. Language learning becoming a commodity concedes the concept of languages as 'skills' merely assisting performance in professional and/or scientific domains. Such utilitarian scope of language application in turn shapes language education according to the needs of the labour market. Significantly enough, the current situation regarding that very labour market requires constant learning, professional enhancement, thus the concept and practice of life-long learning that dominates educational settings today.

Due to this, in hereby only briefly sketched close relationship between globalisation and ESP, it is our aim to emphasise that there are certain cultural, political, ideological, assumptions behind English for Specific Purposes that make it a constituent agent of a globalising phenomenon, which therefore direct the perception of identity in today's world, following the idea of Karl Wilhelm for Humboldt that the 'language that you speak governs all of your perceptions'. The focus of this paper is to show the direct relationship between globalisation and not just English as its medium, but specifically ESP as its medium. Furthermore, the basic point of critique and emphasis is to be the fact that ESP is a 'limited' language in so far as it reduces all language teaching and learning to the linguistic skills necessary and sufficient just for taking an active part in the global economy market.

\section{Characteristics of English (ESP) as a global language}

Languages never exist in isolation, yet today, world languages are undergoing significant changes that are consequences of the changes in their environment. Haugen (1972) suggested the term 
'ecology of language' that indicates the relationship, interdependence of a language and the context in which it functions. His definition of this term is: the study of interaction between any given language and its environment (Haugen 1972, 325). We shall be looking here at English as responding to the demands of its global environment.

Although largely debated upon, and the definition not being reached yet, globalisation shall be here referred to in line with the common thread of many of its meanings, namely, with the idea of connections and relationships reaching and being intertwined across immediate local environments (Gray 2002, 57). For Tomlinson $(1999,2)$ globalization implies intricate connectivity, 'rapidly developing and ever-densening network of interconnections and interdependencies that characterise modern life'. It has been said enough in various strands of social theory how this influences and changes perception, behaviour, identities.

One of the most relevant debates in linguistics according to Seidlhofer $(2003,7)$, is the one on the role of English in this new, global environment. Again, hereby emphasising the role of ESP, we need to say it is the role of ESP in globalisation. The debate centres upon the negative influences of English onto other national languages. That is the first part of our argumentation here. The other is the elaboration of the negative influence of the dominance of ESP as a form of ELT onto today's culture and the perception of it.

The negative influence of English is most strongly formulated in the concepts of 'linguistic imperialism' and 'linguicism'. Linguicism was defined by Phillipson $(1992,47)$, who claims that 'the dominance of English is asserted and maintained by the establishment and continuous reconstruction of structural and cultural inequalities between English and other languages'. In other words, this is a way for the English speaking countries to establish and maintain dominance over the rest of the world. The other concept, 'linguicism', was also defined by Phillipson $(1992,47)$ as 'ideologies, structures, and practices which are used to legitimate, effectuate, and reproduce an unequal division of power and resources (both material and immaterial) between groups which are defined on the basis of language'. This means that the mastery of English language in non-English speaking parts of the world only helps English speaking countries influence and so control various aspects of life there.

As part of this phenomenon, better to say strategy, is the fact that more resources - money, teachers, textbooks, go to the teaching of English than any other language. This is why the critics of English as an agent of globalisation assert that ELT, and especially ESP today, is 
not a neutral activity, i.e. just teaching language, but that it imposes a certain, targeted set of values, ideas, and the way of perceiving the world, all of which marginalises other ways of life as found in other countries and cultures. Another aspect of this, is that ESP, as the language of business, the driving force of the contemporary world, performs a 'gatekeeper function' as the knowledge of it provides access to education, employment and social prestige (Pennycook 2001, 81-2), and at the same time, excludes all those who do not speak it, leaving them with no or little chance for business, commercial, scientific, or academic success.

This way, English for Specific Purposes finds itself at the core of some of the most relevant educational, cultural, and political issues of our time. Teaching and learning the language that is used solely for business or profession for that matter, without any true cultural contents, directly takes a decisive part in producing and reproducing the world order of globalisation. Language is not neutral, but full of discretely present attitudes, ideologies, preferences, layers of social meanings. English for Specific Purposes is a branch of English language teaching that fosters predominantly pre-set, domain specific linguistic education. The aim of such language instruction is to prepare students of any age to accommodate and be competitive in the global market economy. 'In his defining the coordinates of identity in the modern world, H.G.Gadamer $(1996,89)$ emphasized that all thinking originates in language as we can think only in a language. All our experience and reasoning are already pre-conceived by the linguistic presentation of the world. We are linguistically constituted. One of the primary characteristics of language is its collective nature. Its unindividuality is the reason why it is language that speaks and not the human being. Louis-Jean Calvet $(1987,145)$ argued that the changes in languages are not mere linguistic phenomena, but often represent a chapter in the history of a society. The chapter we are witnessing and taking an active part in is globalisation. The language of this chapter is ESP, the language that allows us to strive for a place in business, economy, IT, industry. It is the language that enables us to master the expert vocabulary, to give professional presentations, write documents, have appropriate small talks with colleagues. Yet, it allows us nothing to express our inmost selves, the culture that has nurtured us or that we need for our inner growth. This simply does not fit into the market economy. There is no room for expressing any self apart from the professional one. Culture is dealt with only in so far as it is a desirable adjunct that precedes or proceeds business negotiations. The identity is thus formed according to educational system that favours certain, 
specific, market appropriate character traits and skills. Education that fosters such identity formation is in Lyotard's terms one of 'administrative procedures [that] should make individuals "want" what the system needs in order to perform well' (Lyotard 1984, 62). Stronach and MacLure (1997) also argue more specifically that performativity is gradually changing the very nature of educational research. There is now a demand for 'relevance', immediate policy-pay offs and a direct instrumental contribution to system efficiency.

In ESP the language taught is strictly functional, based on preprepared materials prescribed by experts of the target field of expertise, language skills emphasise the exchange of messages at the expense of issues of culture and identity. It transmits covert ideology of present day liberal capitalism with its underlying social and cultural values. In ESP there is almost no room for encouraging learners, or teachers, to use language in order to think critically about the issues presented and transmitted through that very language. Language has now become a means which allows access to some other kinds of knowledge or social positions. In the philosophy of ESP the knowledge of a language, of English, is not a goal in itself. Learning ESP is significantly different from learning a language with no professional pre-determined purpose, since it is pragmatic, target environment communication oriented, its focus being on preparing students to achieve professional communicative competence. In contrast to this narrowed form of language instruction, a language per se is an ontological skill, insight into unfathomable richness of the meanings of the society and the individual.

In the Postmodern Condition, Lyotard (1984) devotes a whole section to the discussion of 'Education and Its Legitimation through Performativity'. He describes how education, redefined as the transmission of knowledge rather than its pursuit, is driven away from the speculative aims of 'knowledge for its own sake', and towards performativity, whose purposes are efficiency, skills and function. This precisely is the goal of English for Specific Purposes.

The desired goal becomes the optimal contribution of higher education to the best performativity of the social system. Accordingly, it will have to create the skills that are indispensable to that system. These are of two kinds. They vary according to which 'Specialities' the nation-state or major educational institutions can sell on the world market ...

... the transmission of knowledge is no longer designed to train an elite capable of guiding the nation towards its emancipation, but to 
supply the system with players capable of acceptably fulfilling their roles at the pragmatic posts required by institutions. (Lyotard 1984, 40)

\section{ESP as 'applied language' - concluding remarks}

It is our thesis here that English language teaching is moving increasingly towards 'applied language'. Language departments are becoming transformed into service units, providing skills additional to the core capacities required by other areas of professional activity. It has to be admitted that modern languages are by definition a performative skill. Today, ESP is language study associated directly with a discipline other than linguistics or literature, or better to say, clearly dissociated from linguistics and literature as they belong to a species of speculative scholarship positioned at the farthest remove from functionality. In the present day concept of performative education, English is a peripheral or a secondary component, it is a service provision to business. This presumes that complex cultural and existential highlights have no significance in the world of business. ESP courses very rarely contain any critical, cultural or historical component. This again reinforces the perception of English as a global language, as essentially performative.

English language has become a 'commodity', a 'skill'. ESP is part of the framework of utilitarian criteria which directly links decisions about education to the shape of the labour market. Another proof of that is the occurrence and ever larger presence of the socalled 'life long learning'. That market is ever more demanding, and education is never completed, human life is turned into a constant, never ceasing race to keep abreast with the demands of the labour market that needs only ever more productive and competent workers. Therefore, in the rise of ESP we witness the disregard for education in a broad sense and the prevalent need for mere training.

\section{References:}

Haugen, Einar. 'The ecology of language', in A. Dil (ed.) The Ecology of Language: Essays by Einar Haugen. Stanford, CA: Stanford University Press, 1972.

Gadamer, Hans Georg. Pohvala teoriji. Podgorica: Oktoih, 1996.

Gray, John. False Dawn: The Delusions of Modern Capitalism. Granta Books, 2002.

Kalve, Luj Žan. Rat među jezicima. Beograd: Biblioteka XX vek, 1995. 
Lyotard, Jean Francois. The Postmodern Condition: a report on knowledge. University of Minnesota Press, 1984.

Pennycook, Alastair. 'Towards a postcultural curriculum: English, globalization and hybridity:' In W. Renandaya \& N. Sunga (Eds). Language Curriculum and Instruction in Multicultural Societies. Singapore: SEAMEO RELC Anthology Series 42, 2001.

Phillipson, Robert. Linguistic Imperialism. Oxford University Press, 1992.

Seidlhofer, Barbara. Controversies in Applied Linguistics. Oxford University Press, 2003.

Stronach, Ian, \& MacLure, Margaret. Educational Research Undone: the Postmodern Embrace. Oxford University Press, 1997.

Tomlinson, John. Globalization and Culture. The University of Chicago Press, 1999.

\section{STRUČNI ENGLESKI JEZIK KAO LINGVISTIČKI ODGOVOR NA GLOBALIZACIJU}

Stručni engleski jezik jedna je od najskorije ustanovljenih oblasti u nastavi engleskog jezika. Pojavio se u drugoj polovini dvadesetog veka kao rezultat znatnih društvenih promena koje se označavaju terminom 'globalizacija'. Stručni engleski jezik odnosi se na nastavu jezika fokusiranu na precizno i usko definisanu profesionalnu komunikaciju i ima za cilj osposobljavanje studenata za funkcionalnu interakciju, u kojoj jezik postaje sredstvo za ostvarivanje veće profesionalne performativnosti. $U$ takvom se obrazovnom okruženju inherentna ontološka karakteristika jezika zanemaruje. Zbog toga ovaj rad argumentovano prezentuje skrivene kulturološke sadržaje u silabusu stručnog engleskog jezika, i shodno tome iznosi tvrdnju da taj silabus nije bez ideoloških društvenih osobina jer je fokusiran samo na jezik neke profesije. $U$ radu se ističe i posledična potreba da se ovakvom nastavom engleskog jezika favorizuje kritičko mišljenje studenata.

Ključne reči: stručni engleski, globalizacija, performativnost, jezik, sadržaj. 